Plant Tissue Cult. \& Biotech. 22(2): 93-105, 2012 (December)

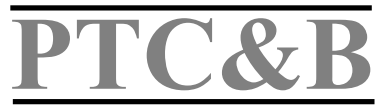

\title{
In vitro Regeneration and Agrobacterium-mediated Transformation of Potato (Solanum tuberosum L.) Cultivars Grown in Mexico
}

\section{Rose Onamu*, Juan P. Legaria, Jaime C. Sahagún, José L. Rodríguez and Joel N. Pérez}

Instituto de Horticultura, Departamento de Fitotecnia, Universidad Autónoma Chapingo, Texcoco, Mexico. Km 38.5, Carretera México-Texcoco. 56230. Chapingo, Estado de México

Key words: Regeneration, Agrobacterium-mediated, Transformation, Potato cultivars

\begin{abstract}
Prior to Agrobacterium-mediated genetic transformation in vitro regeneration protocol was established for three potato cultivars (Alfa, Cambray Rosa Morelos and Atlantic) grown in Mexico using leaf, node and internodal explants. Regeneration protocol was developed with or without the intervention of callus. Two potato cultivars, namely, Cambray Rosa Morelos and Alpha were transformed using Agrobacterium tumefaciens strain LBA4404 harboring binary plasmid pBI121 containing the GUS and nptII genes. GUS histochemical assay and PCR analysis were conducted on rooted shoots grown in media without hormones but supplemented with antibiotics. Transformed shoots tested positive through GUS histochemical assay and integration of nptII gene was confirmed by PCR analysis.
\end{abstract}

\section{Introduction}

In Mexico, potato is cultivated in about 64,000 ha annually having a production of $1.7 \mathrm{Mt}$ with an average yield of $27 \mathrm{t} / \mathrm{ha}$ (FAOSTAT 2007). However, potato is vulnerable to a number of biotic and abiotic factors and several approaches including traditional breeding techniques have been made in the past to overcome these constraints. But in general traditional methods are considered to be complex in nature and take comparatively a longer period to produce a variety with desired characters (Grafius and Douches 2008). To address some of these limitations, plant genetic engineering using desirable genes from various

*Author for correspondence. < ronamu2003@yahoo.co.uk>. 
organisms has provided promising results in improving the yield and quality of potato cultivars (Wierenga et al. 1996, Hefferon et al. 1997, Jeong et al. 2001, Trujillo et al. 2001, Lyapkova et al. 2001, Naimov et al. 2001, Urwin et al. 2001, Chue et al. 2004). Establishment of an efficient in vitro regeneration protocol is a prerequisite to facilitate successful plant genetic transformation (Soto et al. 2007). In this context numerous in vitro regeneration protocols have been developed for potato (Borna et al. 2010, Chakravarty and Wang-Pruski 2010, Shin et al. 2011, Lopéz and Chaparro 2007). Reports are also available regarding the influence of genotype, type of explants and culture conditions on the efficiency of in vitro regeneration in potato cultivars (Sarker and Mustafa 2002). Recently Borna et al. (2010), Chakravarty and Wang-Pruski (2010), Cingel et al. (2010) and Shin et al. (2011) reported successful transformation of potato genotypes. However, transformation protocols are also highly genotype dependent; therefore optimization of transformation protocols has to be realized for any given potato genotype (Vinterhalter et al. 2008). In addition, a few reports exist on the regeneration and transformation of potato cultivars grown in Mexico. The present authors used the existing transformation protocols as reported by Borna et al. (2010) and Cingel et al. (2010) with slightly modification. The objective of the present study was to establish a regeneration protocol and transform potato cultivars grown in Mexico using Agrobacterium tumefaciens harboring GUS and nptII genes.

\section{Materials and Methods}

Three potato (Solanum tuberosum L.) cultivars viz. Cambray Rosa Morelos, Atlantic and Alfa obtained from certified sources in Mexico were used as plant materials for this study. Potato tubers were washed with a detergent in running tap water. They were then dried and stored in brown paper bags with diffuse light in room temperature to obtain sprouts for regeneration experiments. The sprouts were sectioned into $1.0 \mathrm{~cm}$ long pieces including sprout tips. The sections were washed in the detergent and rinsed three times in water. They were then taken to the laminar hood, immersed in $70 \%$ alcohol for $30 \mathrm{sec}$ and then transferred to $10 \%$ bleach solution with Tween 20 for $20 \mathrm{~min}$. The sections were then rinsed three times in sterile distilled water and in MS supplemented with $\mathrm{GA}_{3}$. After every four weeks, nodal explants were prepared for bulking the potato cultivars. Four to eight weeks old explants were used in the regeneration experiments. Internode, nodal and leaf segments of three in vitro grown potato cultivars were used for callus induction and plant regeneration. All cultured plants were grown in MS to which different hormone combinations, $30 \mathrm{~g} / \mathrm{l}$ sucrose and agar at $7 \mathrm{~g} / \mathrm{l}$ were added. The $\mathrm{pH}$ was adjusted to 5.8 before 
autoclaving at $121^{\circ} \mathrm{C}$ and $15 \mathrm{lb}$ psi for $15 \mathrm{~min}$. The cultures were placed in the culture room at $26^{\circ} \mathrm{C}$ and $16 \mathrm{~h}$ photoperiod.

The disinfested explants were cultured on MS containing three different callus induction media (Table 1). The explants with induced callus were transferred to shoot induction media (Table 2) after 3 to 4 weeks depending on how prolific the callus growth was achieved. After four to six weeks shoot induction was observed and shoots $(2.0 \mathrm{~cm}$ long) were transferred to the rooting media without hormones. The shoots rooted after one week in media devoid of hormone.

Agrobacterium tumefaciens strain LBA4404 harboring binary plasmid pBI121 containing the uidA and nptII genes were used in the transformation of the potato cultivars (Fig. 1).

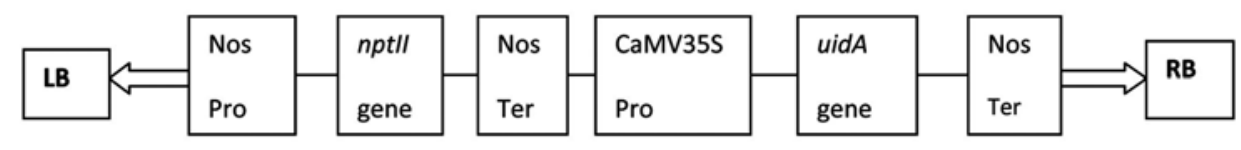

Fig 1. Schematic diagram of the pBI121 vector construct. RB, right border of T-DNA; NOS-Ter, NOS terminator; uidA, GUS ( $\beta$-glucuronidase); CaMV 35S Pro, promoter; nptII, neomycin phosphotransferase gene confers resistance to kanamycin; NOS-Pro, NOS promoter; LB, left border of T-DNA.

Agrobacterium tumefaciens from glycerol stock culture was streaked on to solid YM medium (Yeast extract $0.4 \mathrm{~g}$, Mannitol 10.0 g, NaCl $0.1 \mathrm{~g}, \mathrm{MgSO}_{4} .7 \mathrm{H}_{2} \mathrm{O}$ $0.2 \mathrm{~g}$ and $\mathrm{K}_{2} \mathrm{HPO}_{4} \cdot 3 \mathrm{H}_{2} \mathrm{O} 0.5 \mathrm{~g}$ in a liter of water) at $\mathrm{pH} 7.0 .100 \mathrm{mg} / \mathrm{l}$ streptomycin and $50 \mathrm{mg} / \mathrm{l}$ kanamycin were added for selection of Agrobacterium.

Explants (leaf, node and internode) were cultured on pretreatment media for three days under a photoperiod of $16 \mathrm{hrs}$ light $/ 8 \mathrm{hrs}$ dark. The explants were then inoculated in bacterial suspension containing acetosyringone at $100 \mu \mathrm{M}$ with a dilution of $1: 10$ for $30 \mathrm{~min}$. Thereafter, the explants were co-cultivated on callus induction media in the dark at room temperature for two days. The explants were then rinsed two times in sterile distilled water before incubating in sterile distilled water containing $500 \mathrm{mg} / \mathrm{l}$ of cefotaxime for $30 \mathrm{~min}$. The explants were then blotted dry on sterile filter paper and cultured on callus induction medium containing $300 \mathrm{mg} / \mathrm{l}$ cefotaxime for the elimination of Agrobacterium. The explants were cultured on this media for seven days before transfer to selective callus induction media containing $300 \mathrm{mg} / \mathrm{l}$ cefotaxime and $50 \mathrm{mg} / \mathrm{l}$ kanamycin. After two weeks on selective callus induction media, explants were transferred to selective shoot regeneration media. Induced shoots with a length of $1-2 \mathrm{~cm}$ were excised and rooted in the media without growth regulators but containing 300 $\mathrm{mg} / \mathrm{l}$ cefotaxime and $50 \mathrm{mg} / \mathrm{l}$ kanamycin. Transformed plantlets were selected for further analysis from treatment combinations and explants that recorded 
promising rate of shoot regeneration for each cultivar. Thirty rooted plantlets from each cultivar were subjected to GUS and PCR analysis.

Histochemical assay for the visual detection of GUS gene expression was carried out on 30 regenerated plants obtained from transformed explants according to Jefferson et al. (1987). Histochemical analysis was performed on leaves of kanamycin resistant shoots regenerated on selection medium. The analysis was carried out by incubating the leaves in GUS substrate buffer at $37^{\circ} \mathrm{C}$ for $24 \mathrm{~h}$. Leaves that displayed blue coloration, indicating stable integration of the GUS gene, were recorded as GUS positive. The GUS substrate buffer consisted of X-Gluc $(1 \mathrm{mM})$, potassium ferrocyanide $(5 \mathrm{mM})$, sodium phosphate buffer (100 mM), pH 7.0, Triton X-100 (0.1\%). After GUS staining, the leaves were immersed in methanol : acetone $3: 1$ to remove chlorophyll for ease of observation. The leaves were preserved in $1: 1$ glycerol solution.

Genomic DNA was isolated from 30 GUS positive putative transformants according to Dellaporta et al. (1983). The presence of nptII gene was confirmed by PCR analysis using specific primers (5' -ATGATTGAACAAGATGGATTGCA CGCAGG-3' and 5' GAAGAACTCGTCAA GAAGGCGATA-3'), which delimit an $800 \mathrm{bp}$ fragment from the nptII coding region. The conditions employed for its amplification were $35 \mathrm{cycles}$ at $94^{\circ} \mathrm{C}$ for $30 \mathrm{sec}, 58^{\circ} \mathrm{C}$ for $30 \mathrm{sec}$ and $72^{\circ} \mathrm{C}$ for 45 sec. PCR and DNA gel analysis followed standard procedures (Sambrook et al. 1989).

Thirty explants per treatment were used, each Petri plate containing 10 explants and the treatments were repeated three times. The percentage of both callus induction and shoot regeneration were subjected to arcsine transformation before testing ANOVA (SAS Inst. 2001). Transformed results are presented as per cent, converted back from the arcsine transformation. Means were compared using DMRT in the general linear model procedure $(\alpha \leq 0.05)$ of SAS (SAS Inst. 2001). For transformation experiments, one hundred explants per treatment were used, each Petri plate containing 10 explants and the treatments were repeated three times.

\section{Results and Discussion}

For the induction of callus from different explants, MS supplemented with various auxins and cytokinins were employed. Composition and combinations of hormones used in callus induction media are presented in Table 1. Four different treatments were used. The results of callus induction experiments are shown in Fig. 2. The highest callus induction (100\%) was obtained using nodal explants for Cambray Rosa Morelos (see treatment C1). This was not significantly different from callus inducing capacity of nodal explants for Atlantic $(96.6 \%)$ in 
treatment $\mathrm{C} 1$ and that of Cambray Rosa Morelos in treatment C3 (Fig. 2). The best response for callus induction for Alfa (83.3\%) was obtained with both nodal and leaf explants in treatment C1 (Fig. 2). Comparable callus induction was observed using treatment $\mathrm{C} 1$ in leaf explants for the three cultivars; Cambray Rosa Morelos, Atlantic and Alfa at 80, 80 and 83\%, respectively (Fig. 2). No callus induction from leaf explants was observed in control, treatment C2 for Atlantic and treatment $\mathrm{C} 3$ for all the three cultivars (Fig. 2).

Callus induction has been achieved using auxins alone or at a relatively lower concentration in combination with cytokinins. The response to the type and concentration of auxins and cytokinins used is genotype dependent and also dependent on the type of explants used (Sarker and Mustafa 2002). In the present study, two types of auxins (NAA and IAA) in combination with BA were used to induce callus. The best response was obtained with NAA and BA. Using leaf explants, Cingel et al. (2010) reported similar results for Serbian potato genotypes. Barnerjee et al. (2006) used BAP and NAA and obtained high callus induction using leaf explants with a Solanum tuberosum ssp. andigena. Using NAA and BA, Borna et al. (2010), also successfully induced callus from nodal and internodal explants in three potato cultivars. Using BAP and NAA in the culture medium, Soto et al. (2007) obtained $100 \%$ callus induction in internodal explants of cultivar Desireé. The process of shoot induction either through direct or indirect organogenesis is genotype dependent and also dependent on the genotypes that undergo indirect organogenesis, the callus phase being very crucial. Thus establishment of efficient protocols for callus induction is a prerequisite.

In the present study, the authors also tested a one-step method using BA and IAA. Explants inoculated in this medium regenerated shoots with a low intervening callus. The best callus response (96.6\%) from nodal explants was obtained in Cambray Rosa Morelos in treatment C3 (Fig. 2). Shin et al. (2011) also used BA and IAA for callus induction step in five South Korean potato cultivars in a two-step regeneration protocol.

Table 1. Combinations of various auxins and cytokinins used for the induction of callus from different explants.

\begin{tabular}{lll}
\hline Series & Media* & Hormones used $(\mathrm{mg} / \mathrm{l})$ \\
\hline C1 & CIMI & $4.0 \mathrm{mg} / \mathrm{l} \mathrm{BAP}+1.0 \mathrm{mg} / \mathrm{l} \mathrm{NAA}$ \\
C2 & CIM2 & $2.25 \mathrm{mg} / \mathrm{l} \mathrm{BAP}+1.86 \mathrm{mg} / \mathrm{l} \mathrm{NAA}+10 \mathrm{mg} / \mathrm{l} \mathrm{GA} 3$ \\
C3 & CIM3 & $4.0 \mathrm{mg} / \mathrm{BAP}+1.0 \mathrm{mg} / \mathrm{IAA}$ \\
$\mathrm{C} 4$ & Control & No hormones \\
\hline
\end{tabular}

* CIM = Callus induction media. 


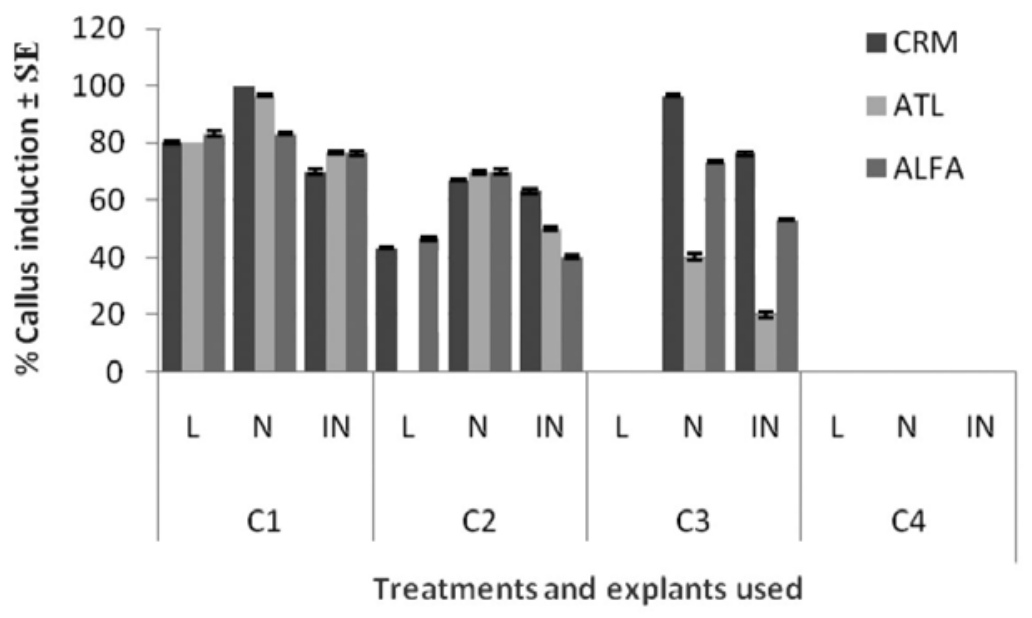

Fig. 2. Per cent callus induction for each treatment in three potato cultivars. In each treatment nodal, internodal and leaf explants were used. Average data taken after four weeks in callus induction media. $\mathrm{CRM}=$ Cambray Rosa Morelos, $\mathrm{ATL}=$ Atlantic, ALFA $=$ Alfa. C1 = CIMI, C2 = CIM2, C3 = CIM3, C4 = Control (details in Table 1). $\mathrm{L}=$ Leaf explants, $\mathrm{N}=$ Nodal explants and $\mathrm{IN}=$ Internodal explants

Callus tissues obtained from different explants were used for the induction of shoots. Various hormonal supplements were employed. Compositions and combinations of hormonal supplements used in callus induction and consequent regeneration of shoots have been presented in Table 2. Five different treatments were used. The results of shoot development experiments are shown in Fig. 3.

The highest shoot regeneration (70\%) was observed in leaf explants of Cambray Rosa Morelos in TI media combination (Fig. 3). This was not significantly different from Treatment Nos. T2, T3 and T4. In similar hormone combinations, Cingel et al. (2010) observed high shoot regeneration (57 - 92\%) in leaf explants of two Serbian potato cultivars. In media T3 regeneration of shoots was the highest $(60 \%)$ for Alfa in which nodal explants were used (Fig. 3). The best response in Atlantic (50\%) was observed in T2 media in which nodal explants were used. Although treatment $\mathrm{C} 1$ had a considerable response for callus induction (Fig. 2), the response for shoot induction was poor for the nodal and internodal explants for the three cultivars in media combination T1 (Fig. 3A). Better shoot regeneration from nodal and internodal explants was obtained when the regeneration media contained BA and IAA; however, this was not observed in Atlantic for treatment combination $\mathrm{T} 3$ where callusing preceded the regeneration phase. 

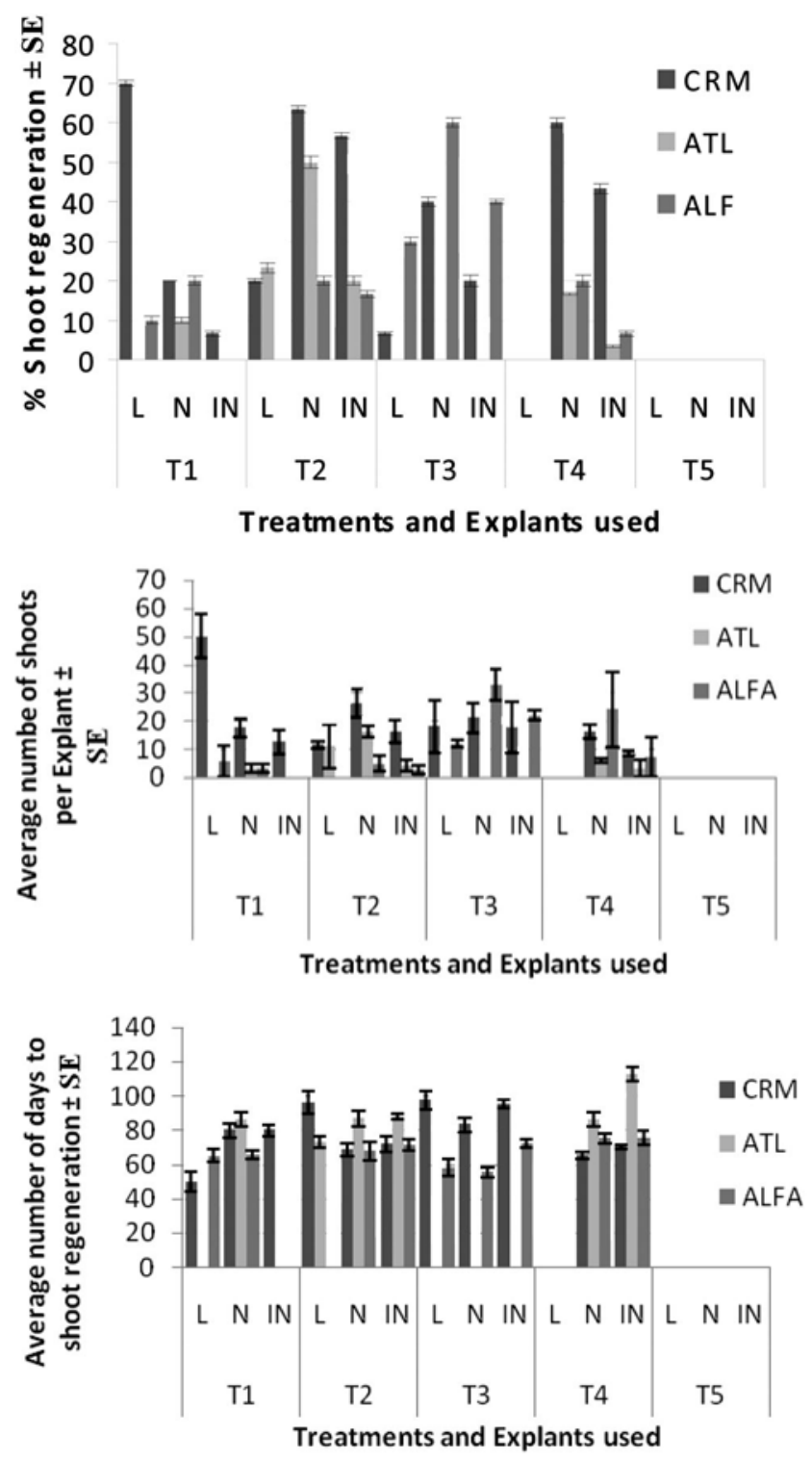

Fig. 3. A. Per cent shoot regeneration. B. Number of shoots per expant. C. Number of days to shoot regeneration for each treatment in three potato cultivars. Nodal, internodal and leaf explants were used in each treatment. CRM, ATL and ALFA are same as in Table 2.

One-step shoot regeneration method (T4) in which nodal explants were used yielded better results $(60 \%)$ in Cambray Rosa Morelos. However, better shoot regeneration from nodal explants was obtained in two-step method for the three potato cultivars (Fig. 3A). 
The highest number of shoots per explant (50) was observed in Cambray Rosa Morelos in T1 treatment combination (Fig. 3B) where leaf explants were used. This was followed by Alfa (32.8) in which nodal explants in T3 media combination were used (Fig. 3B). The best shoot response (16.4) was recorded in Atlantic in T2 media combinations in which nodal explants (Fig. 3B) were used.

Table 2. Media combinations with hormonal supplements for callus induction and eon subsequent regeneration of shoots.

\begin{tabular}{|c|c|c|}
\hline Series & Media combinations* & Hormones mg/l \\
\hline \multirow[t]{2}{*}{$\mathrm{T} 1$} & CIMI & $4.0 \mathrm{mg} / \mathrm{l} \mathrm{BAP}+1.0 \mathrm{mg} / \mathrm{l} \mathrm{NAA}$ \\
\hline & SIMI & $2.0 \mathrm{mg} / 1 \mathrm{BAP}+5.0 \mathrm{mg} / 1 \mathrm{GA} 3$ \\
\hline \multirow[t]{2}{*}{$\mathrm{T} 2$} & CIMI & $4.0 \mathrm{mg} / 1 \mathrm{BAP}+1.0 \mathrm{mg} / \mathrm{l} \mathrm{NAA}$ \\
\hline & SIM2 & $4.0 \mathrm{mg} / 1 \mathrm{BAP}+1.0 \mathrm{mg} / 1 \mathrm{IAA}$ \\
\hline \multirow[t]{2}{*}{ T3 } & CIM2 & $2.25 \mathrm{mg} / \mathrm{l} \mathrm{BAP}+1.86 \mathrm{mg} / \mathrm{l} \mathrm{NAA}+10 \mathrm{mg} / \mathrm{l} \mathrm{GA} 3$ \\
\hline & SIM2 & $4.0 \mathrm{mg} / 1 \mathrm{BAP}+1.0 \mathrm{mg} / 1 \mathrm{IAA}$ \\
\hline \multirow[t]{2}{*}{$\mathrm{T} 4$} & CIM3 & $4.0 \mathrm{mg} / 1 \mathrm{BAP}+1.0 \mathrm{mg} / 1 \mathrm{IAA}$ \\
\hline & SIM2 & $4.0 \mathrm{mg} / 1 \mathrm{BAP}+1.0 \mathrm{mg} / 1 \mathrm{IAA}$ \\
\hline T5 & Control & No hormones \\
\hline
\end{tabular}

${ }^{*} \mathrm{CIM}=$ Callus induction media, SIM = Shoot induction media.

Exclusion of NAA in shoot regeneration medium combination T1 considerably increased the number of shoots per explant in Cambray Rosa Morelos (where leaf explants were used). However, this media did not increase the number of shoots per explant for nodal and internodal explants for all the three cultivars (Fig. 3B). Similar results, namely, 10 shoots per explant were observed by Cingel et al. (2010), using leaf explants. In the present study authors report a relatively higher number of shoots per explant compared to those reported previously. This high number of shoots per explant is comparable to that reported by Borna et al. (2010).

Transformation experiments were conducted in the cultivars of Cambray Rosa Morelos and Alfa using leaf, node and internode explants (Table 3). Callus induction from the infected explants was observed within three to seven days of culture and it was significantly different from that of the control explants without transformation and selection. Among the treatments, the highest callus induction (78.66) was observed in Cambray Rosa Morelos using nodal explants (Fig. 4A). This was not significantly different from callus induction using leaf explants. Best callus induction response for Alfa (60.67) was observed in nodal explants. Shoot regeneration was also significantly different from the controls (data not shown). The highest shoot regeneration $(67.00 \%)$ was recorded in Cambray Rosa Morelos using nodal explants. Similarly, nodal explants 
regenerated the highest number of shoots (40.00\%) with Alfa. Apart from leaf explants, the number of shoots per explant was not significantly different from the controls (data not shown). Culture treatments did not have a significant influence on the number of days to shoot regeneration. The number of days to shoot regeneration was not significantly different from the positive controls (data not shown). Transformation protocols have been reported to influence regeneration abilities of explants in potato (Sato et al. 2007, Cingel et al. 2010, Chakravarty and Wang-Pruski 2010). The chemicals and procedures used in plant transformation protocols have been reported to have toxic effects on plant tissues (Miki and McHugh 2004, Chakravarty and Wang-Pruski 2010). This could be the reason for the significant differences observed in callus induction and shoot regeneration between the controls and treatments.

As has been demonstrated in the present study, Chakravarty and WangPruski (2010), Shin et al. (2011) have reported better regeneration response from stem explants compared to leaf explants. In contrast, Cingel et al. (2010) reported high shoot regeneration from transformed leaf explants of two Serbian potato cultivars. Probably better results may be achieved through further optimization of the transformation protocol based on the type of explant. The best response for shoot regeneration was observed in nodal explants for both cultivars. Borna et al. (2010) also reported high shoot regeneration from nodal explants. Based on data recorded from nodal explants for both cultivars, a total of 300 independent transformed plantlets were obtained, 220 for Cambray Rosa Morelos and 80 for Alfa.

Table 3. Cultivars, explants and culture media used in the transformation of potato plants.

\begin{tabular}{|c|c|c|c|}
\hline Cultivar & Explant & Callus induction & Shoot regeneration \\
\hline \multirow{3}{*}{$\begin{array}{l}\text { Cambray Rosa } \\
\text { Morelos }\end{array}$} & Leaf & $4 \mathrm{mg} / \mathrm{l} \mathrm{BAP}+1 \mathrm{mg} / \mathrm{l} \mathrm{NAA}$ & $2 \mathrm{mg} / \mathrm{lBAP}+5 \mathrm{mg} / \mathrm{l} \mathrm{GA}$ \\
\hline & Node & $4 \mathrm{mg} / \mathrm{l} \mathrm{BAP}+1 \mathrm{mg} / \mathrm{l} \mathrm{NAA}$ & $4 \mathrm{mg} / \mathrm{l} \mathrm{BAP}+1 \mathrm{mg} / \mathrm{l} \mathrm{IAA}$ \\
\hline & Internode & $4 \mathrm{mg} / \mathrm{l} \mathrm{BAP}+1 \mathrm{mg} / \mathrm{l} \mathrm{NAA}$ & $4 \mathrm{mg} / \mathrm{l} \mathrm{BAP}+1 \mathrm{mg} / \mathrm{l} \mathrm{IAA}$ \\
\hline \multirow[t]{2}{*}{ Alfa } & Node & $\begin{array}{l}2.25 \mathrm{mg} / 1 \mathrm{BAP}+1.86 \mathrm{mg} / 1 \\
\mathrm{NAA}+10 \mathrm{mg} / 1 \mathrm{GA} 3\end{array}$ & $4 \mathrm{mg} / 1 \mathrm{BAP}+1 \mathrm{mg} / \mathrm{l} \mathrm{IAA}$ \\
\hline & Internode & $\begin{array}{l}2.25 \mathrm{mg} / 1 \mathrm{BAP}+1.86 \mathrm{mg} / 1 \\
\mathrm{NAA}+10 \mathrm{mg} / 1 \mathrm{GA} 3\end{array}$ & $4 \mathrm{mg} / \mathrm{l} \mathrm{BAP}+1 \mathrm{mg} / \mathrm{l} \mathrm{IAA}$ \\
\hline
\end{tabular}

The results for the 30 plants from each cultivar analyzed for histochemical GUS are shown in Table 4. Leaves from plants that tested GUS positive had a blue color compared to the negative controls which were discolored (Fig. 5). Borna et al. (2010) also demonstrated blue coloration in leaves and nodal 
explants of transformed potato cultivars using histochemical GUS assay. Similarly, Beaujean et al. (1998) observed blue coloration in transformed potato leaves.

Table 4. Percentage of GUS positive plants tested for two potato cultivars grown in Mexico.

\begin{tabular}{lcccc}
\hline Cultivar & $\begin{array}{c}\text { Number of } \\
\text { plants }\end{array}$ & $\begin{array}{c}\text { Number } \\
\text { GUS +ve }\end{array}$ & $\begin{array}{c}\text { Number } \\
\text { GUS -ve }\end{array}$ & $\begin{array}{c}\% \\
\text { GUS +ve }\end{array}$ \\
\hline CRM & 30 & 25 & 5 & 83.3 \\
Alfa & 30 & 27 & 3 & 90 \\
Controls & 10 & 0 & 10 & 0 \\
\hline
\end{tabular}

Transgenic shoots were confirmed by PCR amplification of the nptII gene present within the genomic DNA (Fig. 6) of five randomly selected transformants. Amplified DNA was analyzed through agarose gel electrophoresis. This result indicated that the nptII gene was inserted in the genomic DNA of five transformed potato plantlets.
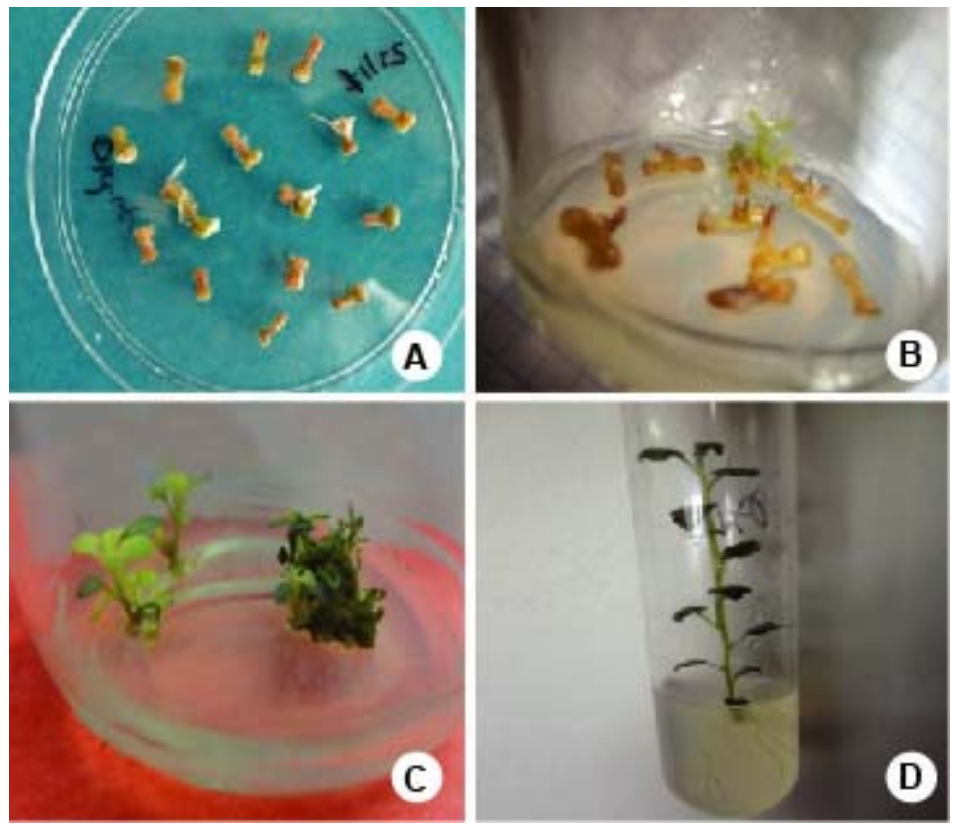

Fig. 4. Callus induction from internodal explants in selection media (A), shoot regeneration in selection media containing kanamycin (B and C), rooted transgenic potato plant (D).

In the present study, regeneration between 21 and $67 \%$ was obtained in transformed potato explants, while transformation (85 to $90 \%$ ) was observed among the cultivars tested. Similar transformation efficiencies have been 
reported by Beaujean et al. 1998, Cingel et al. 2010, Borna et al. 2010, Chakravarty and Wang-Prusky 2010. Incidentally, like the present study these authors used the tuberosum subspecies. In contrast, low regeneration and transformation rates were reported in andigena species (Trujillo et al. 2001, Lopéz and Chaparro, 2007, Valderama et al. 2007). These investigators used a one-step transformation protocol compared to a two-step reported in the present study. In a separate study with andigena species, the investigators obtained high regeneration and transformation efficiencies using a two-step regeneration protocol (Banerjee et al. 2006). Using three potato cultivars from Mexico the transformation protocol

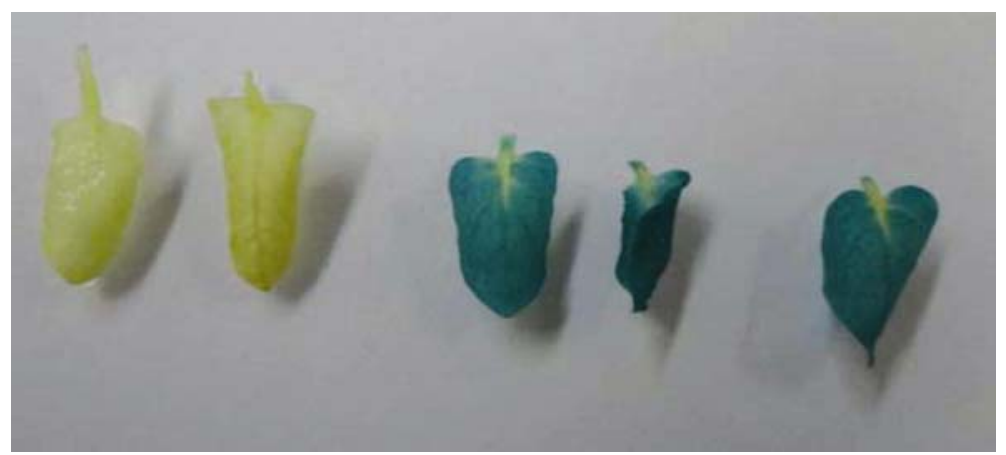

Fig 5. Histochemical localization of GUS activity (blue color) in transformed potato leaves. Left, control untransformed not expressing GUS activity. Right, transformed expressing GUS activity.

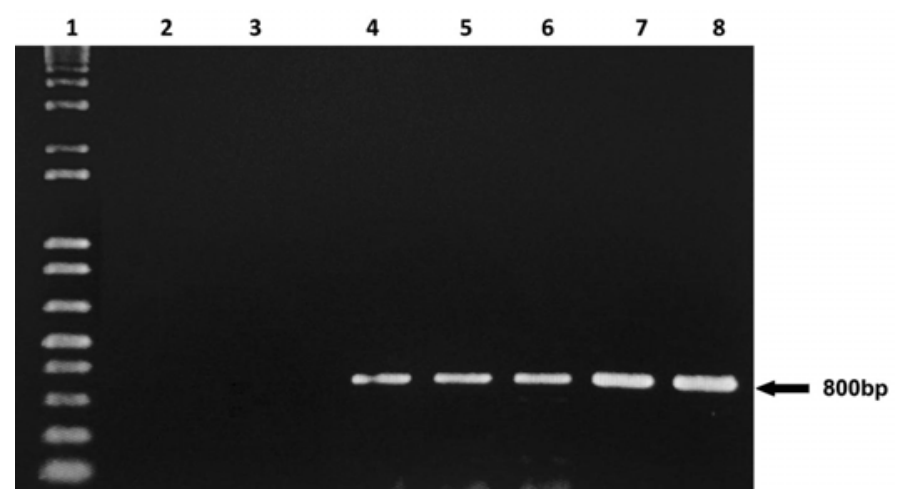

Fig. 6. PCR amplification of nptII gene from transformed plants. Lane 1. Ladder. Lanes 2-3. Genomic DNA from non-transformed potato plants. Lanes 4-8. Amplified DNA of transformed potato plants.

was developed using GUS reporter gene and a selectable marker nptII gene. The transformation technique developed in the present study can be exploited for the development of either biotic or abiotic stress tolerant potato varieties. 


\section{References}

Banerjee AK, Prat S and Hannapel DJ (2006) Efficient production of transgenic potato ( $S$. tuberosum L. ssp. andigena) plants via Agrobacterium tumefaciens mediated transformation. Plant Science, 170: 732-738.

Beaujean A, Sangwan RS, Lecardonnel A and Sangwan-Norreel BS (1998) Agrobacterium-mediated transformation of three economically important potato cultivars using sliced internodal explants: an efficient protocol of transformation. J. Exp. Bot. 49: 1589-1595.

Borna RS, Hoque MI and Sarker RH (2010) Agrobacterium-mediated genetic transformation for local cultivars of potato (Solanum tuberosum L.) using marker genes. Plant Tissue Cult. \& Biotech. 20(2): 145-155

Chakravarty B and Wang-Pruski, G. (2010). Rapid regeneration of stable transformants in cultures of potato by improving factors influencing Agrobacterium-mediated transformation. Advances in Bioscience and Biotechnology.1: 409-416.

Chue ML, Zhao KJ, He ZM, Ramalingam S and Fung KL (2004) An agglutinating chitinase with two chitin-binding domains confers fungal protection in transgenic potato. Planta 220: 717-730.

Cingel A, Branka V, Drangan V, Dragosavac DC, Smigocki A and Ninkovic S (2010) Agrobacterium-mediated transformation of two Serbian potato cultivars (Solanum tuberosum L. cv. Dragacevka and cv. Jelica). African J. Biotechnol. 9(30): 4644-4650.

Dellaporta SL, Wood J and Hicks JB (1983) A plant DNA minipreparation: version II Plant Mol. Biol. Rept. 1: 19-21.

Edwards A, Fulton DC, Hylton CM, Jobling SA, Gidley M, Rossner U, Martin C and Smith AM (1999) A combined reduction in activity of starch synthases II and III of potato has novel effects on the starch of tubers. Plant J. 17: 251-261.

FAOSTAT (2007) Food and Agriculture Organization of the United Nations, FAOSTAT database. 13 Feb. 2007. <http://faostat.fao.org/site/336/default.aspx>.

Grafius EJ and Douches DS (2008) The present and future role of insect- resistant genetically modified potato cultivars. 195-221 pp. In: Integration of insect resistant genetically modified crops within IPM programmes. J. Romeis, A.M. Shelton, G.G. Kennedy (eds.) Springer Science B.V.

Hefferon KL, Khalilian H and AbouHaidar MG (1997) Expression of the PVY (O) coat protein $(\mathrm{CP})$ under the control of the PVX CP gene leader sequence: protection under greenhouse and field conditions against PVY (O) and PVY (N) infection in three potato cultivars. Theor. Appl. Genet. 94: 287-292.

Jefferson RA, Kavanagh TA and Bevan MW (1987) GUS Fusion: $\beta$-glucuronidase as a sensitive and versatile gene fusion marker in higher plants. EMBO J. 6: 3901-3907.

Jeong MJ, Park SC and Byun MO (2001) Improvement of salt tolerance in transgenic potato plants by glyceraldehydes-3 phosphate dehydrogenase gene transfer. Mol. Cells 12: 185-189.

Lopéz A and Chaparro A (2007) Propuesta de un sistema de transformación de plantas de papa (Solanum tuberosum sp andigena var. Pastusa suprema) mediado por Agrobacterium tumefaciens. Agronomía Colombiana 25(1): 16-25. 
Lyapkova NS, Loskutova NA and Maisuryan AN (2001) Transformed potato plants carrying the gene of the antifungal peptide of Amaranthus caudatus. Appl. Biochem. Microbiol. 37: 301-305.

Miki B and McHugh S (2004) Selectable Marker Genes in Transgenic Plants: Applications, Alternatives and Biosafety. J. Biotechnol. 107: 193-232.

Naimov S, Weemen-Hendriks M, Dukiandjiev S and De Maagd RA (2001) Bacillus thuringiensis -endotoxin Cry1 hybrid proteins with increased activity against the Colorado potato beetle. Appl. Environ. Microbiol. 67: 5328-5330.

Sambrook J, Fritsch EF and Maniatis T (1989) Molecular cloning: A laboratory manual, 2nd ed. New York: Cold Spring Harbor Laboratory Press.

Sarker RH and Mustafa B (2002) Regeneration and Agrobacterium-mediated Genetic Transformation of Two Indigenous Potato Varieties of Bangladesh. Plant Tissue Cult. 12: 69-77.

SAS Institute (2001) SAS State software. SAS Institute Inc., Cary, NC., USA

Shin DY, Seong ES, Na JK, Yoo JH, Kang WH, Ghimire BK, Lim JD and Yu CY (2011) Conditions for regeneration and transformation of Solanum tuberosum cultivars using the cotton glutathione S-transferase (Gh-5) gene. African J. Biotechnol. 10(67): 1513515141

Soto N, Enriquez GA, Ferreira A, Corrada M, Fuentes A, Tiel K and Pujol M (2007) Efficient transformation of potato stem segments from cv. Desiree using phosphinothricin as selection marker. Biotech. Applicada 24: 139-144.

Trujillo C, Rodriguez AJ, Jaramillo S, Hoyos R, Orduz S and Arango R (2001) One- step transformation of two Andean potato cultivars (Solanum tuberosum L. sp. andigena). Plant Cell Rep. 20: 637-641.

Urwin PE, Troth KM, Zubko EI and Atkinson HJ (2001) Effective transgenic resistance to Globodera palida in potato field trials. Mol. Breed. 8: 95-101.

Valderrama AM, Velásquez N, Rodríguez E, Zapata A, Zaidi MA, Altosaar I and Arango R (2007) Resistance to Tecia solanivora (Lepidoptera: Gelechiidae) in Three Transgenic Andean Varieties of Potato Expressing Bacillus thuringiensis CrylAc protein. J. Econ. Entomol. 1: 172-9.

Vinterhalter D, Zdravkovi-Kora S, Miti N, Dragicevi I, Cingel A, Raspor M and Ninkovi S (2008) Protocols for Agrobacterium-mediated Transformation of Potato. In: Texeira de Silva J. (ed.) Fruit, Vegetable and Cereal Science and Biotechnology, Global Science Books. pp. 1-15.

Wierenga JM, Norris DL and Whalon ME (1996) Stage specific mortality of Colorado potato beetle (Coleoptera: Chrysomelidae) feeding on transgenic potatoes. J. Entomol. 89: 1047-1052. 